\title{
PENERAPAN SUPERVISI KLINIS OLEH KEPALA SEKOLAH SEBAGAI UPAYA MENINGKATKAN KEMAMPUAN GURU MENGGUNAKAN MODEL PEMBELAJARAN KOOPERATIF DI SEKOLAH DASAR KATOLIK PIGASEMSTER GANJIL TAHUN 2018/2019
}

\author{
Laurensius Waghe \\ lorenzo.waghe68@gmail.com \\ Kepala SDK Piga
}

\begin{abstract}
Tujuan penelitian tindakan sekolah ini adalah untuk meningkatkan kemampuan guru dalam menggunakan model pembelajaran kooperatif di SDK Piga, Kecamatan Soa. Jenis penelitian yang digunakan adalah penelitian tindakan sekolah. Kegiatan dalam penelitian ini terdiri atas tahapan perencanaan tindakan, pelaksanaan tindakan,observasi, dan refleksi. Penelitian ini dilakukan dalam dua siklus. Tempat penelitian di SDK Piga, Kecamatan Soa, Kabupaten Ngada. Subyek dalam penelitian ini adalah guru - guru di SDK Piga yang berjumlah 8 orang, yang terdiri dari 6 orang guru kelas dan 2 orang guru mata pelajaran. Metode pengumpulan data menggunakan metode obeservasi kelas. Analisis data yang digunakan adalah teknik analisis deskriptif komparatif. Data kuantitatif yang diperoleh dideskripsikan dalam bentuk kata-kata atau penjelasan. Selanjutnya dilakukan komparasi data untuk memastikan ada tidaknya peningkatan kinerja guru dalam pelaksanaan pembelajaran di Kelas. Hasil penelitian diketahui pada kondisi awal nilai supervisi klinis kepala sekolah dalam kegiatan pembelajaran diperoleh rata-rata 69,81, pada Siklus I mengalamai peningkatan dengan rata - rata peroleh nilai pada supervisi klinis sebesar 76,92 mengalami peningkatan sebesar 7,11. Pada siklus II nilai supervisi klinis diperoleh rata - rata 83,08 . Mengalami peningkatan dari siklus I ke Siklus II sebesar 6, 16. Dari data ini berarti terjadi peningkatan nilai supervise klinis kepala sekolah dalam kegiatan pembelajaran dari kondisi awal hingga akir siklus II sebesar 13, 93\%.

Hal ini dapat disimpulkan bahwa dengan Penerapan Supervisi Klinis Oleh Kepala Sekolah dapat Meningkatkan Kemampuan Guru Menggunakan Model Pembelajaran Kooperatif di Sekolah Dasar Katolik Piga semster Ganjil Tahun 2018/2019
\end{abstract}

Kata kunci: supervisi klinisk, kemampuan guru, model pembelajaran kooperatif 


\section{PENDAHULUAN}

Keberhasilan kepala sekolah dalam melaksanakan tugasnya banyak ditentukan oleh kepemimpinan kepala sekolah. Kepemimpinan merupakan faktor yang paling penting dalam menunjang tercapainya tujuan organisasi sekolah. Keberhasilan kepala sekolah dalam mengelola kantor, mengelola sarana prasarana sekolah, membina guru, atau mengelola kegiatan sekolah lainnya banyak ditentukan oleh kepemimpinan kepala sekolah. Apabila kepala sekolah mampu mempengaruhi, menggerakkan, membimbing, dan mengarahkan anggota secara tepat, segala kegiatan yang ada dalam organisasi sekolah akan bisa terlaksana secara efektif. Sebaliknya, bila tidak bisa menggerakkan anggota secara efektif, tidak akan bisa mencapai tujuan secara optimal.

Dalam melaksanakan tugasnya kepala sekolah dituntut untuk selalu meningkatkan efektifitas kerja. Menurut Mulyasa (2007:126), kepemimpinan kepala sekolah yang efektif meliputi: (1) Mampu memberdayakan guru-guru untuk melaksanakan proses pembelajaran dengan baik, lancar, dan produktif.
(2) Dapat menyelesaikan tugas dan pekerjaan sesuai dengan tenggat waktu yang telah ditetapkan. (3) Mampu menjalin hubungan yang harmonis dengan masyarakat sehingga dapat melibatkan mereka secara aktif dalam rangka mewujudkan tujuan sekolah dan pendidikan. (4) Berhasil menerapkan prinsip kepemimpinan yang sesuai dengan tingkat kedewasaan guru dan pegawai lain di sekolah. (5) Bekerja dengan tim manajemen. (6) Berhasil mewujudkan tujuan sekolah secara produktif sesuai dengan ketentuan yang telah ditetapkan. Seperti yang telah dikemukakan di atas, ada beberapa kepemimpinan kepala sekolah yang efektif yang harus diterapkan oleh kepala sekolah sesuai dengan situasi, kebutuhan, serta motivasi para guru dan staf.

Sebagai pemimpin pendidikan, kepala sekolah memiliki sejumlah tugas dan tanggung jawab yang cukup berat. Untuk bisa menjalankan fungsinya secara optimal, kepala sekolah perlu menerapkan gaya kepemimpinan yang tepat. Fungsi dan tugas kepala sekolah dapat diakronimkan menjadi emanslime (education,manager, 


\begin{abstract}
administrator, supervisor, leader, inovator, motivator dan entrepreneur). Peran tersebut dapat dilihat secara lebih rinci sebagai berikut; a) Peran sebagai educator, kepala sekolah berperan untuk mempengaruhi dan menggerakan dalam pembentukan karakter yang didasari nilai-nilai pendidik sebagai berikut
\end{abstract}

kemampuanmengajar/membimbing peserta, dan membimbing membimbing guru; b) Peran sebagai manager,kepala sekolah berperan untuk mempengaruhi dan menggerakan sumber daya untuk mencapai tujuan institusi secara efektif dan efisien yaitu memiliki kemampuan menyusun program sekolah, menyusun program serta mampu menggerakan warga sekolah; c) Peran sebagai administrator, kepala sekolah berperan dalam mempengaruhi dan menggerakan tata aksana sistem administrasi di sekolah sehingga efektif dan efisien yang meliputi memiliki kemampuan mengelola administrasi pembelajaran, administrasi peserta didik , administrasi ketenagaan, dan administrasi keuangan dan sarana prasarana; d) Peran sebagai supervisor, kepala sekolah berupaya membantu mengembangkan profesionalitas guru dan tenaga kependidikan lainnya. Kepala sekolah harus memiliki beberapa kemampuan sebagai berikut memiliki kemampuan menyusun program supervise pendidikan, melaksanakan program supervisi, dan memanfaatkan hasil supervise.

Menurut Jones (dalam Mulyasa, 2003 : 155 ), supervise merupakan bagian yang tidak dapat terpisahkan dari seluruh proses administrasi pendidikan yang ditujukan terutama untuk mengembangkan efektifitas kinerja personalia sekolah yang berhubungan dengan tugas - tugas utama pendidikan.

Sebagai supervisor kepala sekolah melaksanakan tugasnya sesuai yang diamanatkan undangundang melalui Permendiknas nomor 15 tahun 2018 tentang Pemenuhan Beban Kerja Guru, Kepala Sekolah, dan Pengawas Sekolah yakni tugas a) merencanakan program supervisi guru dan tenaga kependidikan; b) melaksanakan supervisi guru; c) melaksanakan supervisi terhadap tenaga kependidikan; d) menindaklanjuti hasil supervisi 
terhadap Guru dalam rangka peningkatan profesionalisme Guru; e) melaksanakan Evaluasi Supervisi Guru dan Tenaga Kependidikan. Supervisi kepala sekolah merupakan upaya seorang kepala sekolah dalam pembinaan agar guru dapat meningkatkan kualitas mengajarnya melalui langkah - langkah perencanaan, penampilan mengajar yang nyata serta mengadakan perubahan dengan cara yang rasional dalam usaha meningkatkan hasil belajar siswa.

Salah satu bentuk supervise kepala sekolah adalah supervise klinis. Secara umum supervisi klinis diartikan sebagai bentuk bimbingan profesional yang diberikan kepada guru berdasarkan kebutuhannnya melalui siklus yang sistematis. Siklus sistematis ini meliputi: perencanaan, observasi yang cermat atas pelaksanaan dan pengkajian hasil observasi dengan segera dan obyektif tentang penampilan mengajarnya yang nyata (dalam Muhtar dan Iskandar,2009:47). Sedangkan Richard Waller (dalam Ngalim Purwanto,2006) menyatakan bahwa supervisi klinis merupakan salah satu model supervisi yang difokuskan pada peningkatan kemampuan mengajar melalui siklus yang sistematis, baik dalam perencanaan, pengamatan serta analisis yang intensif tentang penampilan mengajar yang nyata, serta berujuan mengadakan perubahan dengan cara yang rasional. Sehingga disimpulkan supervisi klinis adalah suatu proses bimbingan yang bertujuan untuk membantu pengembangan profesionalitas guru khususnya dalam penampilan mengajar, berdasarkan observasi dan analisis data secara teliti dan objektif sebagai pegangan untuk perubahan tingkah laku mengajar guru. Jadi, inti dari supervisi klinis adalah berfokus pada penampilan dan perilaku mengajar guru.

Supervisi yang dilakukan oleh kepala sekolah salah satunya adalah implementasi pembelajaran guru di dalam kelas atau pelaksanaan proses pembelajarn. Peningkatan kualitas pembelajaran salah satu factor penentunya adalah peningkatan kualitas guru.

Tenaga guru dituntut mampu menunjukkan kompetensinya sebagai guru yang profesional. Mulyasa $(2003,45)$ mengemukakan lima kompetensi dasar yang harus 
dimiliki oleh seorang guru yang profesional yaitu : (1) Penguasaan kurikulum, (2)

penguasaan materi pelajaran, (3) penguasaan metode dan tehnik evaluasi, (4) komitmen terhadap tugas, dan (5) disiplin dalam arti luas.

Guru yang memiliki Kompetensi tinggi akan bersikap kreatif dan inovatif yang selamanya akan mencoba dan mencoba menerapkan berbagai penemuan baru yang dianggap lebih baik untuk pembelajaran siswa.

Kompetensi guru bukan hanya dalam tataran desain perencanaan pembelajaran, akan tetapi juga dalam proses dan evaluasi pembelajaran. Dalam aspek perencanaan misalnya, guru dituntut untuk mampu mendesain perencanaan yang memungkins secara terbuka siswa dapat belajar sesuai dengan minat dan bakatnya., seperti Kompetensi merumuskan tujuan pembelajaran, Kompetensi menyusun dan menyajikan materi atau pengalaman belajar siswa, Kompetensi untuk merancang desian pembelajaran yang tepat sesuai dengan tujuan yang akan dicapai, Kompetensi menentukan dan memanfaatkan media dan sumber belajar, serta Kompetensi menentukan alat evaluasi yang tepat untuk mengukur keberhasilan proses pembelajaran. Kompetensi dalam proses pembelajaran berhubungan erat dengan bagaimaa cara guru mengimplementasikan perencanaan pembelajaran, yang mencakup kompetensi menerapkan keterampilan dasar mengajar dan keterampilan mengembangkan berbagai model pembelajaran yang dianggap mutakhir.Sedangkan keterampilan mengembangkan model pembelajaran seperti keterampilan proses, model pembelajaran, metode klinis, dan pendekatan pembelajaran.

Salah satu pendekatan dalam proses pembelajaran adalah Pendekatan pembelajaran cooperative learning. Cooperative Learning berasal dari kata cooperative yang artinya mengerjakan sesuatu secara bersama-sama dengan saling membantu satu sama lainnya sebagai satu kelompok atau sebagai satu tim. Pembelajaran kooperatif (Cooperatif Learning) merupakan strategi belajar dengan sejumlah siswa sebagai anggota kelompok 
kecil yang tingkat kemampuannya berbeda. Dalam menyelesaikan tugas kelompoknya, setiap siswa sebagai anggota kelompok harus saling bekerjasama dan saling membantu untuk memahami materi pelajaran. Dalam kooperatif learning, belajar dikatakan belum selesai, jika salah satu teman dalam kelompok belum menguasai bahan pelajaran (Isjoni, 2011).

Depdiknas (dalam Komalasari, 2015: 62) menyatakan bahwa pembelajaran kooperatif (cooperative learning) merupakan Strategi pembelajaran melalui kelompok kecil siswa yang saling bekerja sama dalam memaksimalkan kondisi belajar untuk mencapai tujuan belajar.

Dari hasil supervise pembelajaran untuk 8 guru di SDK Piga ditemukan $50 \%$ atau 4 orang guru yang belum kreatif menggunakan model pembelajaran maupun teknik pendekatan yang baru, akibatnya mutu pembelajaran menurun $(8,7 \%)$ atau 9 siswa yang tidak naik ketingkat berikutnya dari jumlah siswa seluruh 103 orang, pada akhir tahun pelajaran 2017/2018.
Selain itu ditemukan juga, guru dalam melaksanakan pembelajaran tanpa menggunakan RPP yang dibuat sendiri, mereka cenderung menggunakan RPP copy paste dan belum melaksanakan pembelajaran berpusat kooperatif.Guru masih melaksanakan pembelajaran dengan metode ceramah murni yang bersifat klasikal, belum maksimal menggunakan alat peraga, dan jarang melakukan pembelajaran yang kreatif seperti model pembelajaran kooperatif, yang dapat melatih mandiri dan tanggungjawab para peserta didik.

Berdasarkan kondisi ini peneliti dalam pelaksanaan tugasnya adalah sebagai kepala sekolah berupaya agar semua guru dalam melaksanakan pembelajaran berpusat dengan model pembelajaran kooperatif, sesuai dengan ketentuan yang ada dalam Standar Proses dalam Permendiknas nomor 22 tahun 2016. Ketentuan itu merupakan pedoman yang harus diwujudkan dalam proses pembelajaran oleh guru yang merupakan pimpinan di kelas itu. Apabila semua guru dalam melaksanakan tugasnya setiap hari mengajar dengan berpusat 
kooperatif di kelasnya, maka dapat dikatakan, bahwa hasil dari proses pembelajaran itu akan tercapai memuaskan, yang pada gilirannya akan meningkatkan prestasi belajar para peserta didiknya.

Dengan menggunakan model pembelajaran kooperatif diharapkan dapat mengatasi persoalan yang dihadapi diatas. Oleh Karena itu tujuan dari penelitian ini adalah untuk mengetahui peningkatan keampuan Guru Menggunakakan Model Pembelajaran Kooperatif Di Sekolah Dasar Katolik Pigasemster Ganjil Tahun 2018/2019 melalui supervise klinis kepala sekolah.

\section{METODE PENELITIAN}

Penelitian ini merupakan penelitian tindakan sekolah (School Action Research), karena penelitian dilakukan untuk memecahkan masalah proses pembelajaran di sekolah. Rancangan penelitian yang digunakan adalah rancangan model Kemmis yang terdiri dari atas empat langkah, yakni: perencanaan, pelaksanaan, observasi dan refleksi (Wardhani, 2007: 45). Penelitian dilaksanakan selama 2 bulan yaitu bulan 03 September - 31 Oktober 2018. Penelitian tindakan sekolah ini dilaksanakan di Sekolah Dasar Katolik Piga, tahun pelajaran 2018/2019. Subyek penelitian adalah guru - guru di SDK Piga yang disupervisi oleh kepala sekolah sebanyak 8 orang. Penelitian ini akan dilaksanakan dalam dua siklus, dan langkah - langkah dalam setiap siklus terdiri dari perencanaan, pelaksnaan tindakan, observasi, dan refleksi. Metode atau teknik pengumpulan data menggunakan teknik obeservasi selama proses tindakan penelitian oleh supervisor dalam hal ini kepala sekolah. Instrument yang digunakan adalah pedoman observasi. Instrumen observasi yang digunakan berupa alat penilaian kompetensi guru (APKG) dalam pelaksanaan Pembelajaran yang terdiri dari Pedoman Observasi Penilaian Rencana Pelaksanaan Pembelajaran ( RPP) dan Pedoman Observasi Penilaian Pelaksanaan Pembelajara. Analisis data yang digunakan peneliti dengan menggunakan analisis deskriptif komparatif, yaitu dengan membandingkan pelaksanaan pembelajaran sebelum dilaksanakan supervisi klinis, dan pembelajaran sesudah dilakukan supervisi klinis. 
Indikator keberhasilan yang dapat diukur adalah meningkatnya kemampuan guru dalam mengelola proses pembelajaran dengan model pembelajaran kooperatif sehingga memperoleh kriteria BAIK atau berada pada rentang 80 - 89 maka penelitian dikatakan berhasil.

\section{HASIL DAN PEMBAHASAN}

Kondisi awal kemampuan guru dalam melakukan proses pembelajaran masih bersifat konvensional. Adapun sebagai subjek penelitian yaitu guru kelas dan guru mata pelajaran di Sekolah Dasar Piga sebagai daerah binaan peneliti sebagai kepala sekolah. Dari hasil supervisi yang dilakukan peneliti, diperoleh data guru-guru tersebut belum memiliki kemampuan maksimal dalam melaksanakan pembelajaran berpusat yang mengarah pada pendekatan paikem. Dari 8 orang guru terdapat 4 orang guru dengan kategori kurang dan 4 orang lainya masih dalam kategori cukup. Untuk itu peneliti akan melakukan tindakan agar semua guru mampu melaksanakan pembelajaran Paikem dengan model pembelajaran kooperatif secara maksimal. Namun demikian peneliti selaku pengawas sekolah menyadari bahwa dalam melaksanakan superviisi belum maksimal, karena itu Pengawas Sekolah sebagai peneliti berupaya melakukan tindakan kegiatan.

Guru melakukan pengelolaan pembelajaran melalui pendekatan Paikem dengan model pembelajaan yang modern yaitu model pembelajaran kooperativ tampak kurang maksimal. Hal ini dapat dilihat dari data yang diperoleh dalam penilaian RPP maupun proses pembelajaran , berarti belum ada yang nampak baik. Mereka hanya mengajar menggunakan buku teks yang dimiliki tanpa memperhatikan silabus dan RPP bahkan ada yang langsung mengerjakan LKS. Metode yang digunakan hanya ceramah tidak bervariasi dan tugas mengerjakan soal saja. Ada beberapa guru belum menggunakan alat peraga, sedangkan guru yang menggunakan alat peraga tersebut belum maksimal. Perbaikan dan pengayaan juga belum dilakukan dengan baik.

Hasil penelitian Siklus I dapat diketahui bahwa skor nilai pembelajaran guru kelas dan guru 
mata pelajaran di SDK Piga secara individu yaitu : terdapat 2 orang atau $25 \%$ berada pada rentangan nilai 80 - 89, berada pada kategori baik. Terdapat 6 orang atau $75 \%$ berada pada rentang nilai $70-79$ berada pada kategori cukup. Sedangkan secara klasikal rataratanya adalah $76,92 \%$ termasuk masih dalam kategori cukup (kurang memuaskan). Dari data tersebut menunjukan bahwa rata-rata kemampuan guru dalam menerapkan model pembelajaran kooperatif dalam kategori cukup meskipun ada guru yang sudah masuk dalam kategori baik.

\section{Berdasarkan Indikator} keberhasilan dalam penelitian ini adalah penelitian dikatakan berhasil apabila meningkatnya kemampuan guru dalam mengelola proses pembelajaran dengan model pembelajaran kooperatif dengan memperoleh kriteria BAIK atau berada pada rentang $80-89$. Dari hasil analisis data di atas maka penelitian ini belum sesuai dengan indikator keberhasilan, karena rata rata nilai adalah $76,92 \%$ berada pada kategori cukup.
Pelaksanaan siklus II dapat di ketahui perolehan nilai individu berkisar 80 - 89, berada pada kategori baik. Rata-rata skor secara klasikal adalah $83,08 \%$ berada pada kategori baik. Berdasarkan indikator kinerja penelitian ini telah mencapai kategori baik dengan rata - rata prerolehan secara individu sberkisar 80 - 89 berada pada kategori baik secara klasikal diperoleh rata - rata sebesar $83,08 \%$ berada pada kategori baik. Rata-rata keseluruham adalah 83,08 atau masuk dalam kategori baik berarti guru - guru SDK Piga mampu melaksanakan pembelajaran kooperatif dalam kegiatan pembelajarn. Penelitian ini dinyatakan berhasil dan berhenti sampai pada siklus II saja.

Dalam penelitian ini penggunaan supervise klinis dapat meningkatkan kemampuan guru dalam menggunakan model pembelajaran kooperatif di SDK Piga, Kecamatan Soa, Kabuaten Ngada.

Berdasarkan hasil tindakan pada siklus I dan II di dapat dirangkum ke dalam tabel 1 berikut ini yaitu dari data awal, siklus 1, dan siklus 2. Pada mutu pembelajaran 
terjadi peningkatan dari data awal sampai akhir siklus II

Tabel 1 Nilai Sepervisi Klinis Siklus I dan Siklus ||

\begin{tabular}{|l|c|c|}
\hline $\begin{array}{l}\text { Kegiata } \\
\mathrm{n}\end{array}$ & Nilai & Peningkatan \\
\hline $\begin{array}{l}\text { Kondisi } \\
\text { Awal }\end{array}$ & 69,81 & \\
\hline Siklus I & 76,92 & 7,11 \\
\hline Siklus II & 83,08 & 6,16 \\
\hline $\begin{array}{l}\text { Rat - Rata } \\
\text { peningkatan }\end{array}$ & $13,93 \%$ \\
\hline
\end{tabular}

Dari tabel di atas dapat diketahui pada kondisi awal nilai supervise klinis kepala sekolah dalam kegiatan pembelajaran diperoleh rata-rata 69,81 , pada Siklus I mengalamai peningkatan dengan rata - rata peroleh nilai pada supervise klinis sebesar 76,92 mengalami peningkatan sebesar 7,11 . Pada siklus II nilai supervise klinis diperoleh rata - rata 83,08 . Mengalami peningkatan dari siklus I ke Siklus II sebesar 6, 16. Dari data ini berarti terjadi peningkatan nilai supervise klinis kepala sekolah dalam kegiatan pembelajaran dari kondisi awal hingga akir siklus II sebesar 13, 93\%. Berdasarkan data tersebut dapat dilakukan pembahasan bahwa Penelitian Tindakan Sekolah tentang peneraan supervisi klinis oleh kepala sekolah sebagai upaya meningkatkan kemampuan guru dalam menggunakan model pembelajaran kooperatif di SDK Piga dapat dikatakan berhasil karena terjadi peningkatan skor pada mutu pembelajaran. Hal ini lebih terlihat jelas pada tabel di atas. Walaupun masih belum

sempurna, namun sudah mendekati pada skor maksimal dalam arti ada peningkatan yang memuaskan.

Penerapan supervise klinis dapat meningkatkan kemampuan guru dalam menggunakan model pembelajaran. Model pembelajaran yang diambil dalam penelitian ini adalah model pembelajarn kooperatif. Guru yang memiliki Kompetensi tinggi akan bersikap kreatif dan inovatif yang selamanya akan mencoba dan mencoba menerapkan berbagai penemuan baru yang dianggap lebih baik untuk pembelajaran siswa. Kompetensi dalam proses pembelajaran berhubungan erat dengan bagaimaa cara guru mengimplementasikan perencanaan pembelajaran, yang mencakup kompetensi menerapkan keterampilan dasar mengajar dan keterampilan mengembangkan berbagai model pembelajaran yang 


dianggap mutakhir.Sedangkan
keterampilan mengembangkan
model pembelajaran sepert
keterampilan proses, mode
pembelajaran, metode klinis, dan
pendekatan pembelajaran.
Salah satu pendekatan dalam
proses pembelajaran adalah

Pendekatan pembelajaran cooperative learning merupakan konsep belajar yang membantu guru mengaitkan antara materi yang diajarkan dengan situasi dunia nyata siswa dan mendorong siswa membuat hubungan antara pengetahuan yang dimilikinya dengan penerapannya dalam kehidupan mereka sebagai anggota keluarga dan masyarakat.

Keith Acheson dan Meredith D. Gall menyatakan bahwa supervisi klinis adalah proses membantu guru memperkecil kesenjangan antara tingkah laku mengajar yang nyata dengan tingkah laku yang ideal ( Ngalim Purwanto: 2006). Pelaksanaan supervise dapat dilakukan oleh kepala sekolah. Dalam melaksanakan supervisinya, kepala sekolah berupaya menyediakan kondisi kerja yang terbuka supaya masalah yang akan dipecahkan diketahui terlebih dahulu. Pemahamannya tentang supervisi bukan saja harus menyediakan waktu untuk melakukan kunjungan ke dalam kelas untuk melakukan observasi dan mengikuti berbagai pertemuan, melainkan juga meliputi penyediaan kondisi kerja yang menguntungkan dan memberi kemudahan pada guru-guru dalam melaksanakan tugasnya.

Berdasarkan uraian diatas, dan sesuai dengan teori - teori pendukung serta kajian hasil - hasil penelitian yang relevan yang diambil sebagai refrensi dalam penelitian ini terbukti bahwa penerapan supervise klinis dapat meningkarkan kemampuan guru menggunakan model pembelajaran kooperatif di SDK Piga, Kecamatan Sos, Kabupaten Ngada Tahunpelajaran 2018/2019.

\section{PENUTUP}

\section{Simpulan}

$\begin{array}{lcr}\begin{array}{r}\text { Supervisi } \\ \text { meningkatkan }\end{array} & \begin{array}{c}\text { klinis } \\ \text { pemahanan }\end{array} & \text { dapat } \\ \text { kemampuan } & \text { guru } & \text { dalam }\end{array}$
menggunakan model pembelajaran kooperatif di SDK Piga, Kecamatan Soa, Kabupaten Ngada, tahunpelajaran 2018/2019, terbukti 
dengan hasil penelitian diketahui pada kondisi awal nilai supervise klinis kepala sekolah dalam kegiatan pembelajaran diperoleh rata-rata 69,81 , pada Siklus I mengalamai peningkatan dengan rata - rata peroleh nilai pada supervise klinis sebesar 76,92 mengalami peningkatan sebesar 7,11. Pada siklus II nilai supervise klinis diperoleh rata - rata 83,08. Mengalami peningkatan dari siklus I ke Siklus II sebesar 6, 16. Dari data ini berarti terjadi peningkatan nilai supervise klinis kepala sekolah dalam kegiatan pembelajaran dari kondisi awal hingga akir siklus II sebesar $13,93 \%$.

Dari data diatas dapat disimpulkan bahwa Penerapan Supervisi Klinis Oleh Kepala Sekolah dapat Meningkatkan Kemampuan Guru Menggunakan Model Pembelajaran Kooperatif Di Sekolah Dasar Katolik Piga semster Ganjil Tahun 2018/2019.

\section{Saran}

Berdasarkan temuan - temuan ini disarankan beberapa hal antara laian : kepada kepala sekolah hendaklah tetepa menerapkan pelaksanaan supervise klinis kepada guru secara berkala, sehingga guru selalu menyiapkan dirinya baik dalam penyiapan perangkat pembrlajaran maupun penyiapan dalam hal proses pemmbelajaran dikelas dengan selalu menggunakan model, metode maupun strategi mengajar kooperatif maupun inovatif

\section{DAFTAR PUSTAKA}

A. Mulyasa. 2003. Kurikulum Berbasis Kompetensi. Bandung: Remaja Rosda Karya.

A. Mulyasa, 2007. Standar Kompetensi dan Sertifikasi Guru. Bandung:PT.Remaja Rosdakarya.

I.G.A.K. Wardani. 2007. Penelitian Tindakan Kelas. Jakarta: Universitas Terbuka KTSP SD/MI 2011

Isjoni. 2011. Pembelajaran Kooperatif. Yogyakarta: Pustaka Pelajar

Komala sari, Kokom. 2015. Pembelajaran kontekstual konsep dan aplikasi, Bandung : refika aditama

Mukhtar \& Iskandar. 2009. Orientasi Baru Supervisi Pendidikan. Jakarta: Gaung Persada Press. Mulyasa. 2006. Kepala Sekolah Profesional. Bandung

Permendikbud Nomor 22 Tahun 2016 Tentang Standar Proses Pendidikan Dasar dan Menengah 
Permendikbud Nomor 15 tahun 2018.

Tentang Pemenuhan Beban

Kerja Guru, Kepala Sekolah,

dan Pengawas Sekolah 